\title{
Cognitive maps in early entrepreneurship stages
}

\section{From motivation to implementation}

\section{Susana Correia Santos, Luís Curral and António Caetano}

\begin{abstract}
The purpose of this research is to contribute to the explanation of cognitive maps during early entrepreneurship stages. Three groups were selected to represent different developmental states in early entrepreneurship. Individual interviews were conducted, the data were computer content analysed and cognitive maps were extracted. The results show that entrepreneurship experience develops the structure of cognitive maps, increasing clarity, richness and experience-based features. The originality of the research resides in the inclusion of entrepreneurial motivation in business opportunity recognition and the decision to launch a venture model. Through a cross-sectional design, a temporal perspective is captured by including different entrepreneurship stages.
\end{abstract}

Keywords: early-stage entrepreneurship; cognitive maps; qualitative analysis; entrepreneurial motivation

Susana Correia Santos is a PhD student at ISCTE - IUL - Lisbon University Institute, Avenida das Forças Armadas, Edifício ISCTE, Room 124 AA, 1649-026 Lisboa, Portugal. E-mail: susana.santos@iscte.pt. Luís Curral is Assistant Professor, Faculty of Psychology, Lisbon University, Alameda da Universidade, 1649-013 Lisboa, Portugal. E-mail: luis.curral@ fpce.ul.pt. António Caetano is a Full Professor at ISCTE - IUL - Lisbon University Institute, Portugal. E-mail: antonio.caetano@iscte.pt.

Entrepreneurship has been widely studied through management, economics, political science and psychology frameworks (for example, Baron and Shane, 2005; Levenburg, Lane and Schwarz, 2006). Despite this increasing interest in entrepreneurship research and its recognized importance in modern societies, there are still limited explanations regarding some aspects of its cognitive and behavioural processes.

The entrepreneurial process can be depicted in a sequence of six stages - (1) recognition of an opportunity; (2) decision to launch a venture; (3) assembling the resources; (4) actual launch of the new venture; (5) building a successful business; and (6) harvesting the rewards (Baron and Shane, 2005). Across all the entrepreneurship stages, proximal, mezzo and distal factors have important consequences for their successful conclusion and the decision-making process. For example, opportunity recognition is a crucial stage that occurs as a cognitive process accomplished by specific individuals, and thus reflects their unique life stories and previous experiences. Moreover, the mental processes through which we acquire, store, transform and retrieve information and data are crucial to idea generation (Baron, 1998). However, nothing to do with people happens in a social vacuum - whether cognitions, motives or decision making. Thus, the ideas people generate reflect the periods in which they live, the current state of technology and scientific knowledge, the actual government policies and so many other factors (Baron and Shane, 2005). So entrepreneurship has been 
progressively described as a multidimensional construct, including different levels of factors.

Besides the economic and managerial aspects of the entrepreneurship process, the process lacks the inclusion of entrepreneurial motivation. Moreover, a critical aspect that research has not yet thoroughly analysed concerns the three early stages, from entrepreneurial motivation to business implementation: entrepreneurial motivation, business opportunity recognition and decision to launch a venture.

As Baron (2006) highlighted, it is important to know the processes involved in early entrepreneurship stages in order to establish an integrative model and also to improve academic training programmes and practices targeted at young people, promoting the spirit of entrepreneurship in high school and university. The literature (for example, Shane, Locke and Collins, 2003) lacks any treatment of the integration of these initial entrepreneurship process stages.

This study seeks to extend previous knowledge regarding the integration of business opportunity recognition, the decision to launch a venture prototype and entrepreneurial motivation, answering the scientific developments in Baron and Ensley's (2006) and Shane, Locke and Collins's (2003) previous works. So this study aims at contributing to the explanation of the early entrepreneurship stages, from business opportunity recognition to the decision to launch a venture.

The main research question this study addresses is: how do different entrepreneurial experience levels influence the structure and evolution of cognitive maps at the early entrepreneurship stages? More specifically, we strive to state the differences between three groups in the three early entrepreneurship stages - entrepreneurial motivation, business opportunity and the decision to launch a venture.

Specifically, the present research used a qualitative approach, comparing three different groups of entrepreneurs with different experience patterns:

entrepreneurship trainees (individuals who attend a postgraduate course in entrepreneurship), would-be entrepreneurs (individuals who are six months away from launching their entrepreneurial project) and novice entrepreneurs (one-experience entrepreneurs).

This research design allows us to answer the following specific questions: What are the main motivations underlying early entrepreneurship stages? How do people recognize business opportunities? How does a decision to launch a venture occur? To answer these questions, a model was developed connecting entrepreneurial motivation, business opportunity recognition and the decision to launch a venture.

Baron and Ensley (2006) discussed prototype entrepreneurial features that characterize business opportunities and the decision to launch ventures, comparing novices with experienced entrepreneurs. Our study represents a step forward in entrepreneurship research as it presents entrepreneurs' cognitive relationships among recognized features through cognitive maps. More specifically, it presents the cognitive maps of the motivation, business opportunity and decision to launch, including not only the prototypical features, but also the relationship between them.

Moreover, this study is innovative in comparing the cognitive framework between early stages of entrepreneurship, that is, among entrepreneurship trainees, would-be entrepreneurs and novice entrepreneurs. Understanding cognitive maps changing at these early stages may be particularly important for designing educational strategies that promote knowledge concerning how entrepreneurial activity evolves and increases entrepreneurship.

Theoretically, the present research contributes to developing knowledge regarding the early entrepreneurship stages, as it: (a) clarifies relations between the entrepreneurial motivation, business opportunity and the decision to launch a venture through cognitive maps; and (b) allows a development perspective by means of comparing entrepreneurship trainees, would-be entrepreneurs and novice entrepreneurs.

\section{Entrepreneurship: the motivational driver}

Entrepreneurship is most commonly defined as the process by which 'opportunities to create future goods and services are discovered, evaluated, and exploited' (Shane and Venkataraman, 2000, p 218). Accordingly, entrepreneurship activity is the result of motivated human action and external factors (Shane, Locke and Collins, 2003).

Evidence from qualitative and quantitative research suggests that motivation influences the entrepreneurial process (Shane, Locke and Collins, 2003). Shane et al's (2003) model identifies general and task-specific entrepreneurial motivations that have direct effects on opportunity recognition, idea development and execution. General motivations include the need for achievement, locus of control, vision, desire for independence, passion and drive. Task-specific motivations include goal setting and self-efficacy. Moreover, Baum and Locke (2004) determined that situationally specific motivation (that is, communicated vision, self-efficacy and goals) had direct effects on venture growth. More recently, McGee, Peterson, Mueller and Sequeira (2009) evidenced the importance of entrepreneurial selfefficacy to a new venture creation process as a core feature of entrepreneurial motivation.

A meta-analysis of 47 studies revealed that achieve- 
ment motivation was significantly correlated with entrepreneurial performance and the choice of an entrepreneurial job (Collins, Hanges and Locke, 2004). Despite the many studies focused on entrepreneurial motivation (for example, Vijaya and Kamalanabhan, 1998), the results are still not comprehensively integrated into an explanation of the entrepreneurial process, especially the initial stages of business opportunity recognition and the decision to launch a venture.

\section{Business opportunity recognition and the decision to launch a venture}

Entrepreneurial business opportunity research has focused mainly on the discussion around its operationalization and its nature. How the opportunities are recognized is still one of the central questions of entrepreneurship research (Smith, Matthews and Schenkel, 2009; McMullen, Plummer and Acs, 2007).

With regard to operationalization, business opportunities involve the bringing into existence of new goods, services, raw materials and organizing methods that allow outputs to be more profitable, that is, they can be sold at a higher price than their cost of production (Shane, 2003). In general, the definition includes three characteristics: potential economic value, novelty and perceived desirability (Baron, 2006). Recently, the need to link the micro-analytic research results and the macro level of social and economic theory has been seen as critical to understanding the origins of opportunity (Plummer, Haynie and Godesiabois, 2007).

Concerning its nature, the research has followed two different approaches. Most American researchers suggest that opportunities exist 'out there', and they are available to be discovered. On the other hand, some European researchers have argued that entrepreneurial opportunities emerge from an entrepreneur's perception, interpretation and understanding of the environment (Dutta and Crossan, 2005).

In an attempt to resolve this discrepancy, Kickul and Gundry (2000) suggested an integrative approach. Concerning their multidimensional and complex nature, entrepreneurial opportunities would emerge from the recognition of profitable scenarios.

As an integrative approach, Shane (2003) developed a general theory of entrepreneurship in which opportunities are thought of as existing before their recognition. Their perception depends on the characteristics of opportunities (for example, high-growth industries) and the characteristics of the people who exploit them (Casson, 2005). Despite the important contribution of this approach, Shane (2003) does not specifically include the motivational role in the entrepreneurship process.
Moreover, no comprehensive framework has been given to business opportunity or the decision to launch a venture. Focusing on the perception of both steps, and based on pattern recognition theory, Baron $(2004,2006)$ suggested that individuals perceived business opportunities as they perceived connections between apparently unrelated events or trends - for example, changes in technology, demographics, markets or government policies - as a meaningful pattern. The crucial assumption in this approach is that opportunities are recognized rather than constructed. Entrepreneurs' cognitive frameworks, the so-called entrepreneurs' mental schemes or maps (for example, Bird, 1988) or prototypes, may be developed on the basis of pattern recognition. The entrepreneur's cognitive framework, by 'connecting the dots' between perceived unrelated environmental changes, permits the recognition of meaningful patterns that are possible venture opportunities. For instance, when an entrepreneur finds that any of his/her prototypes fits the perceived environmental patterns, a business opportunity may emerge and the decision to launch a venture can occur (Baron, 2006).

Baron and Ensley (2006) offered the first empirical paper on the 'connecting the dots' approach to entrepreneurial opportunity recognition. As qualitative exploratory research to test the assumption that entrepreneurship opportunity recognition operates as pattern recognition, the authors conducted interviews with novice (first-time) and repeat (experienced) entrepreneurs aiming to compare business opportunity prototypes. They simply asked the participants to 'describe the idea on which your new venture was based' and 'why did you feel this was a good idea - one worth pursuing?' The first question allowed the identification of the business opportunity prototype and the second one allowed the identification of the decision to launch a venture prototype. The data collected in that study were content analysed with Ethnograph, which reports frequencies of words, and, in addition, panel members identified distinct ideas or attributes present in the entrepreneurs' responses. After a strict procedure, Baron and Ensley (2006) identified that a business opportunity prototype included: (1) solving a customer's problems, (2) the ability to generate a positive cash flow, (3) manageable risk, (4) superiority of the product/ service, and (5) potential to change the industry. Regarding a decision to launch a venture, they identified the following prototypical features: (1) a favourable financial model, (2) positive assessment or advice from others (friends, financial advisers and industry experts), (3) the idea's novelty, (4) a large untapped market, and (5) intuition or gut feeling.

Evidence shows that experienced entrepreneurs have prototypes that are clearer, richer and more venture- 
focused on business opportunities and the decision to launch a venture prototype than novice entrepreneurs (Baron and Ensley, 2006). These results support the assumption of opportunity recognition as pattern recognition and identify a variety of factors that constitute the business opportunity and the decision to launch prototypes.

\section{From pattern recognition to cognitive maps}

Baron's (2006) 'connecting the dots' approach to business opportunities and the decision to launch is based on pattern recognition theory - the process through which individuals perceive complex and apparently unrelated events as meaningful patterns (Matlin, 2005). Within this approach, prototypes are considered as representations of the most typical features that characterize one category (Rosch, 1977). In pattern recognition theory, a prototype can be described by templates, feature lists or structural descriptions (Palmer, 1977). The process involves the comparison of the input pattern with the highly specific dimensions of the categorical representation stored in the memory - the prototype. The decision strategy is based on the perceived computed similarity between the input pattern and the categorical prototype (Palmer, 1977).

Basically, every time a new event or trend is perceived, it is compared with the memory-stored prototype, and its specific features or possible connections are evaluated. This process has been explored, for instance, in social psychology (for example, Bonito, 2004; Curseu, Schruijer and Boros, 2007), experimental psychology (Intraub, Bender and Mangels, 1992) and more recently in entrepreneurship research (Baron and Ensley, 2006).

Prototypes can be considered as a specific type of mental (or cognitive) model, as they represent the mental world, which, in turn, is a representation of the real world (Palmer, 1977). In entrepreneurship research, prototypical features that characterize a business opportunity and the decision to launch a venture have already been described (Baron and Ensley, 2006). We can go further than the description of the features in the entrepreneurial process and also include the analysis of the relationships among the categories. So the present research intends to represent the entrepreneur's mental model graphically through cognitive maps.

Cognitive maps may be constructed as graphic devices that individuals use to represent and associate categories and ideas with special issues (Eden and Ackermann, 1992; Langfield-Smith, 1992; Tolman, 1948). In the map, categories are graphically represented by nodes and are linked by causal relationships or means to achieve a given goal that is situated at the arrow's tail (Carbonara and Scozzi, 2006).

Different methodologies have been proposed to assess cognitive maps. Semi-structured interviews have been used as the main approach to data collection (Eden, 1988; Laukkanen, 1998). Other elicitation techniques include content analysis, repertory grid techniques, factor analysis, adjacency matrices, interactive interviewing (for example, Self-Q) and semiotic analysis (Swan, 1995). Some of these approaches can be classified as nomothetic methods that require participants to select from a predefined set of categories and focus on the relationships between them (Goodhew, Cammock and Hamilton, 2005); and others are ideographic methods, which allow the inclusion of free categories (Cossette and Audet, 1992). More recent methodologies turn to software packages, such as Decision Explorer or CMAP2 (Cossette and Audet, 1992).

As this has been used as one of the main methodologies to study cognitive maps (for example, Eden, 1988), this research collected semi-structured individual interviews to draw cognitive maps. Although responses to the questionnaires commonly used in these studies do not provide an understanding of the association or relationship between factors, cognitive mapping does. Specifically, we use cognitive maps to explain the different factors interacting during the stages of motivational process, business opportunity recognition and the decision to launch a venture, and to describe, analyse and compare three different entrepreneurs' groups. In other words, 'in what way' do different groups structure knowledge concerning initial entrepreneurship stages? Evidence of how knowledge is structured between different developmental entrepreneurship groups has the potential to shed light on whether early entrepreneurship stages are perceived differently, thereby leading to different practical implications.

\section{The present research}

Although Baron and Ensley (2006) identified the main factors that characterize business opportunity recognition and the decision to launch a venture prototype, theirs is still a preliminary model as it does not consider other crucial factors that may interfere in the process, such as motivational factors. As the development of any entrepreneurship theory requires consideration of the motivations of people making entrepreneurial decisions (Shane, Locke and Collins, 2003), it is important to examine the relationship between them.

In this study, three groups were selected to represent different developmental states in early entrepreneurship: entrepreneurship trainees are characterized by entrepreneurial motivation and are looking for opportunity 
Table 1. Developmental features of the groups in the research.

\section{Entrepreneurship trainees Entrepreneurial motivation Would-be entrepreneurs Novice entrepreneurs \\ Entrepreneurial motivation Entrepreneurial motivation \\ Recognizing opportunities \\ Opportunity recognized \\ Opportunity recognized}

Deciding to launch a venture

Decision to launch a venture Implementing of entrepreneurial project recognition; would-be entrepreneurs have entrepreneurial motivation and have already decided to launch a venture, as they will be founding their project within six months; and finally, novice entrepreneurs have already implemented their entrepreneurial projects. Thus, these three groups have different but sequential developmental features, characterizing the three critical early stages in the entrepreneurship process (Table 1). The present study will analyse this changing process through cognitive maps, describing factors of motivation, business opportunity and the decision to launch.

The literature reveals that longitudinal research into entrepreneurship is difficult and scarce (Davidson, 2004). Although the present research is cross-sectional, it may be considered as proxy-like for a longitudinal perspective, as it has three different groups that correspond to three different developmental stages. Thus, the present research in some way seeks to fill this gap in the literature. Moreover, the three groups chosen can allow us to grasp the changing pattern of entrepreneurs' cognitive maps, allowing the inference of their evolutionary and developmental perspective, depending on the groups' experience level and ability for decision making: from entrepreneurship trainees to novice entrepreneurs, or from entrepreneurial motivation to entrepreneurial project implementation.

This study proposes a bidirectional-mediation framework (Figure 1). The entrepreneurial process begins with motivation and aims to reach the decision to launch a venture. Despite the powerful effect of entrepreneurial motivation, the decision to launch a venture requires the recognition of business opportunities. Thus, business opportunity recognition may play a mediating role between entrepreneurial motivation and the decision to launch a venture. At the beginning of the entrepreneurial process, motivation is a critical factor, catalysing the development of the process. Without strong, focused, general and task-specific motivations, the entrepreneurship process is unable to proceed (Shane, Locke and Collins, 2003).

Bidirectional entrepreneurial motivation promotes business opportunity recognition as an elaborated and mediated cognitive process to the decision to launch a venture. Business opportunity recognition has to be systematically fed by entrepreneurial motivation, creating a bidirectional and dynamic effect. It is

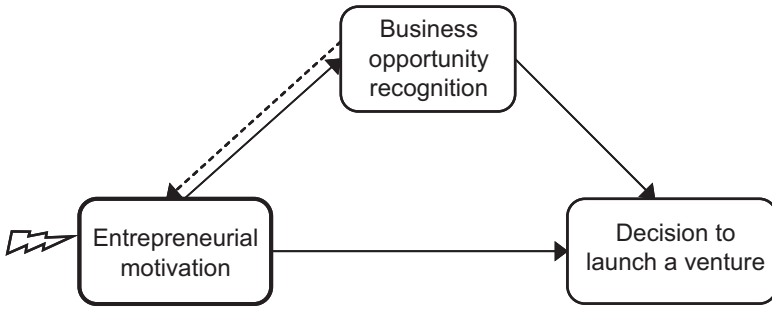

Figure 1. Entrepreneurship early stages process: proposed model.

assumed that opportunities are perceived from the environment as meaningful patterns (Baron, 2006). When perceived events or trends assume prototypical features that are critical to pattern recognition, a business opportunity emerges.

The decision to launch a venture is the output from the early stages in the entrepreneurship process, according to the existence of essential factors that are perceived as indispensable to the continuation of the entrepreneurship process. The decision to launch a venture occurs when their meaningful features are recognized as prototypical of a pattern (Baron and Ensley, 2006), which is similar to business opportunity recognition.

As the entrepreneurship process is involved on multilevel factors, such as the proximal, mezzo and distal factors (Baron and Shane, 2005), in addition to analysing the cognitive maps' structures, we intend to study the social and individual factors that they may comprise. The literature already provides evidence that the entrepreneurship process is multidimensional and requires the interaction of different domain variables (for example, Shane, 2003). Thus, it was predicted that macro-social, micro-social, individual and cognitive factors would be crucial to the ability to move from entrepreneurial motivation to the decision to launch a venture. With regard to macro-social factors, economic, professional and technological variables were considered (for example, Begley, Tan and Schoch, 2005). At the micro-social level, family, friends and colleagues (for example, Siqueira, 2007) were taken into account. At the individual level, motivation and personality (for example, Zhao and Seibert, 2006) variables were considered. Finally, regarding cognitive factors, it was predicted that decision making, opportunity recognition 
and problem-solving strategies (for example, Baron, 1998) would be central during the early stages of entrepreneurship.

\section{Method}

\section{Participants}

Altogether, 18 participants were involved in this study. The sample consisted of three groups: seven entrepreneurship trainees, five would-be entrepreneurs and six novice entrepreneurs. The average age was 31.7 years, and one participant was female. Their ages ranged from 23 to 51 , with a standard deviation of 8.6 years.

Entrepreneurship trainees. The participants attended a graduate-level training course in entrepreneurship and venture launch at a Portuguese university business school. All the participants have an undergraduate degree, and two have a Master's degree.

Would-be entrepreneurs. The would-be entrepreneurs were participants who were preparing their own entrepreneurship project to be started within six months.

Sixty per cent have an undergraduate degree, and all are employed. Entrepreneurial projects include Internetbased services, human resources recruitment, design and creative ateliers and biotechnology applications.

Novice entrepreneurs. All the participants have had their own business, lasting on average for 2.8 years, with a range of 6 months to 5 years and a standard deviation of 1.9 years. All the entrepreneurs were engaged in their first entrepreneurial project and all the ventures were located in the Metropolitan Area. All the entrepreneurs have an undergraduate degree (management, physical engineering or sociology) and one of them has a postgraduate degree in entrepreneurship and venture launch; $90 \%$ of them had previously been employed in other firms before starting their own business. Entrepreneurial firms include strategic marketing consulting, market research services, editorial commerce and a targeted event organizer.

\section{Procedure and data analysis}

A qualitative approach was chosen as it was stated to be one of the most powerful approaches to developing the early stages of entrepreneurship research (for example, Bygrave, 2007; Davidson, 2004). More specifically, with regard to motivational drivers, business opportunities and the decision to launch a venture, the qualitative approach is the most powerful research approach.

Within the qualitative approach, semi-structured interviews were assigned as the most appropriate method of collecting data on the above research topics (for example, Baron and Ensley, 2006; Shane, Locke and Collins, 2003).

The data were content analysed on ATLAS-ti, version 5.0 (Muhr, 2004). The option to use computer-aided text analysis was based on the empirical and theoretical evidence of the clear advantage of processing large samples with high speeds and reliabilities (Short et al, 2009). The analysis with this computer content analysis software follows a research methodology based on grounded theory (for example, Strauss and Corbin, 1998).

The option for this method is based on the objectives of the research. As we are interested in explaining the process rather than measuring the contribution of each key stage, the grounded theory approach serves this purpose because it develops theory that is grounded in data (Strauss and Corbin, 1998) and describes a formal set of procedures that guide a reliable qualitative analysis (Henwood and Pidgeon, 2003). The ATLAS-ti software supports the data analysis based on the grounded theory paradigm and enhances the bidirectional process between the data and the researcher's assumptions (for example, Henwood and Pidgeon, 2003).

Each participant was individually interviewed and the data were recorded. The data were all collected during a period of approximately one month. The main questions were: 'What motivated you to start entrepreneurial activity?' 'Describe the idea on which your venture was based' and 'Why did you feel that was a good idea - one worth pursuing?' The last two questions were used by Baron and Ensley (2006). We also asked participants to describe their professional and relevant personal life path until the present time. Data were transcribed verbatim and the content analysed with ATLAS-ti, a powerful program for coding and interpreting textual data (Barringer, Jones and Neubaum, 2005). The narratives were coded using standard content analysis techniques (Lincoln and Guba, 1985). The minor discrepancies that existed between the coders were resolved by examining the data together.

The cases were initially coded at the sentence level with each substantive sentence assigned to one or more of four categories. The sentences were then analysed to identify variables, such as prior entrepreneurial experience, business opportunity sources and venture launch decision making. Examples of how the coding was performed are provided in Table 2.

As the process of induction of theory from data (Henwood and Pidgeon, 2003), the codes and memos were data created. The data analysis was based on the main literature concepts. The final step was the graphic representation of the relationships between the concepts in analysis. 
Table 2. Examples of data coding for the three early entrepreneurship stages in the case study sample (the three groups are included).

\section{Coding category \\ Entrepreneurial motivation \\ Passion for work}

Work independence

Work autonomy

\section{Economical motivation}

Dissatisfaction with working culture Family support

Market opportunity

Entrepreneurship teamwork

Ambition

Business opportunity recognition Social corporate responsibility Partner's idea

Policy knowledge

Innovative concept

International professional experience Social demographic context Socioeconomic world development Family business opportunity idea

Decision to launch a venture

Passion for work

New in the market

Technical market knowledge

Market acceptance

Business creation know-how Financial fund available

\section{Example}

'If I can choose to work on the business area that I love, [...] I have to accomplish this desire." I love what I do, and I would never change my occupation. [...]'

'I can take my decisions, [...]'

'I can work independently from greater hierarchical positions [...]'

'I can manage my time [...], I can choose where to work [...]"

It's possible to manage the family-work time easily'

'I feel that I can receive more income if I work for myself [...]'

'I need to improve my monthly salary [...]'

I don't like the working culture where I was working [...]'

'My family is, somehow, also involved in the project [...]'

'I feel that my family can give me some advice and management experience [...]'

'I identified a market opportunity [...]'

'I can see clearly that I may provide this service in a more efficient way [...]'

'I can choose the persons who will work with me [...]'

'It's a privilege when you can choose the best partners for your entrepreneurial team [...]'

'Only with my own business I feel like I have conquered what I dream about [...]'

'I had the clear vision that I would be an entrepreneur [...]'

'I still can feel that I have the energy to go further and to develop more business [...]'

'I know that my business develops better ways to serve our society [...]'

'My partner had a great business idea, and I joined him [...]'

'The law concerning the [...] is changing; thus, it's important to exploit this gap [...]'

'There isn't anything similar in the market [...]'

'We will provide a different and innovative service/product [...]'

'My working experience abroad allowed me to see that the market had a specific need for [...]' 'The social demographic context is changing [...]; this is a clear business opportunity [...]'

'The change in the socioeconomic worldwide patterns evidence that there is a gap [...]'

'My brother had this idea [...]; I am applying that idea [...]'

'It was a business area already performed by my relatives [...]'

'I love my business [...]' 'I love what I do [...]'

'We could assess clearly the newness of the product in the market [...]'

'I know how the market works [...]'

'These technical issues are currently a need on the market [...]'

'I assessed whether my clients would accept my product [...]'

'The acceptance in the market [...] is critical to the decision [...]'

'I have know-how on business creation [...]'

'The initial financial investment was available [...]'

'We had the money to make the first investment [...]'
With regard to internal validity, three independent raters evaluated the data, and inter-rater reliability was computed based on Cohen's $2 \times 2$ unweighted kappa (Cohen, 1960) through an Excel program developed to assist researchers in the determination and presentation of confidence intervals. The results revealed an acceptable agreement $(\mathrm{kappa}=0.58)$, meaning that the analysis could proceed.

\section{Results}

Entrepreneurship trainees', would-be entrepreneurs' and entrepreneurs' cognitive maps on entrepreneurial motivations, business opportunity recognition and the decision to launch a venture were extracted. The elicited categories with a direct association with each early entrepreneurship stage process are presented in Table 3.

\section{Entrepreneurial motivation}

Entrepreneurship trainees identified several motivations towards entrepreneurship (Figure 2). They identified entrepreneurship as part of a passion for work and the wish to go further. Entrepreneurship motivations are mainly individual factors. They are an active response to the trainee's current professional situation: unemployment threat and remaining active (in the case of some pre-retirement trainees). Moreover, 'my own business' desire is also associated with entrepreneurship motivation, as it reflects a social responsibility, a personal 'fingerprint' or a personal investment. The dissatisfaction with local working cultures and economic motivation is also identified. Work autonomy motivation is the only working condition identified, as it is associated with independence and higher development ability. 
Table 3. Categories with direct association with the corresponding cognitive map target: entrepreneurial motivation, business opportunity recognition and decision to launch a venture (categories in italic represent an 'is part of' relationship).

\begin{tabular}{|c|c|c|c|}
\hline & Entrepreneurial motivation & $\begin{array}{l}\text { Business opportunity } \\
\text { recognition }\end{array}$ & Decision to launch a venture \\
\hline Entrepreneurship trainees & $\begin{array}{l}\text { Passion for work } \\
\text { Wish to go further } \\
\text { 'My own business' } \\
\text { Dissatisfaction with } \\
\text { working culture } \\
\text { Economic motivation } \\
\text { Remain in activity } \\
\text { Work autonomy }\end{array}$ & $\begin{array}{l}\text { Group brainstorming } \\
\text { Observation } \\
\text { Policy knowledge } \\
\text { Gap in the market } \\
\text { Job experience } \\
\text { Emotional business } \\
\text { opportunity identification } \\
\text { Partner's idea } \\
\text { Market necessity } \\
\text { Social corporate responsibility }\end{array}$ & $\begin{array}{l}\text { Passion for work } \\
\text { New to the market } \\
\text { Market problem } \\
\text { Policy knowledge } \\
\text { Technical market knowledge } \\
\text { Financial funds } \\
\text { Differentiation from the } \\
\text { competitors } \\
\text { Market acceptance } \\
\text { Viability } \\
\text { Value chain profitable }\end{array}$ \\
\hline Would-be entrepreneurs & $\begin{array}{l}\text { Work flexibility } \\
\text { Entrepreneurship teamwork } \\
\text { Decision-making autonomy } \\
\text { Work autonomy } \\
\text { Passion for work } \\
\text { Family support } \\
\text { Dissatisfaction }\end{array}$ & $\begin{array}{l}\text { Entrepreneurship teamwork } \\
\text { Market with ethical problem } \\
\text { Entrepreneurship management } \\
\text { knowledge } \\
\text { Socioeconomic world } \\
\text { development } \\
\text { Innovative concept } \\
\text { Family business opportunity idea }\end{array}$ & $\begin{array}{l}\text { Trust in business idea } \\
\text { Passion for work } \\
\text { New investment area } \\
\text { Small investment } \\
\text { Market acceptance } \\
\text { Small competition patterns } \\
\text { Business creation know-how } \\
\text { Market opportunity }\end{array}$ \\
\hline Entrepreneurs & $\begin{array}{l}\text { Autonomy } \\
\text { Work flexibility } \\
\text { Overlap with studied area } \\
\text { Entrepreneurship teamwork } \\
\text { Passion for work } \\
\text { Ambition } \\
\text { Small risk } \\
\text { Independence }\end{array}$ & $\begin{array}{l}\text { Socio-demographic context } \\
\text { Risk taking } \\
\text { International professional } \\
\text { experience } \\
\text { Freelancer } \\
\text { Market problem }\end{array}$ & $\begin{array}{l}\text { Ability to solve market's } \\
\text { problems } \\
\text { Financial resources available } \\
\text { Independence } \\
\text { Passion for work } \\
\text { Entrepreneurship teamwork }\end{array}$ \\
\hline
\end{tabular}

Would-be entrepreneurs identified motivations underlying the desire to launch a venture in three factors: work design - work flexibility, autonomy and decision-making autonomy are associated with the motivation to develop an entrepreneurial project; working conditions - to have the opportunity to choose the entrepreneurial teamwork involved; life path - a dissatisfaction with their life path, associated with an unpleasant life context; the recognition of a market opportunity and passion for work are associated with the motivation to develop an entrepreneurial project.

Similarly, their families had some entrepreneurship experience, which provided some family support. There is an associative triangle between work autonomy, work flexibility and the motivation to develop an entrepreneurial project; and passion for work, market opportunity and the motivation to develop an entrepreneurial project.

Motivations underlying novice entrepreneurs' wish to launch a venture emerge from four factors: work design - the ability to have greater work autonomy, flexibility and independence is identified as crucial and associated with the perception of the chance to have a better quality of life; working conditions - the chance to choose and work with their own entrepreneurial team and the possibility of having their own business in their aca- demic specialization area were motivating working conditions; financial condition - entrepreneurs referred to the controllable risk underlying their venture projects, and they had family support; life path - entrepreneurs associated their motivation to launch a venture with a high level of ambition and passion for work.

\section{Business opportunity recognition}

Business opportunity recognition factors (Figure 3) are linearly identified by entrepreneurship trainees. Business idea recognition is associated with observation, policy knowledge, gaps in the market, a partner's idea, market necessity, social corporate responsibility, job experience, emotional identification and group brainstorming.

Would-be entrepreneurs associate it with ethical problems in the market (for example, firms whose products have a lower quality than claimed), as they distrust these practices and assume the opportunity as corporate social responsibility. Business opportunities can also be identified by members of the family who are also entrepreneurs. Thus, business opportunity recognition is associated with the perceived knowledge of entrepreneurship management. The development of a world socioeconomy and innovative concepts are also associated with business opportunity recognition. 
Entrepreneurship trainees

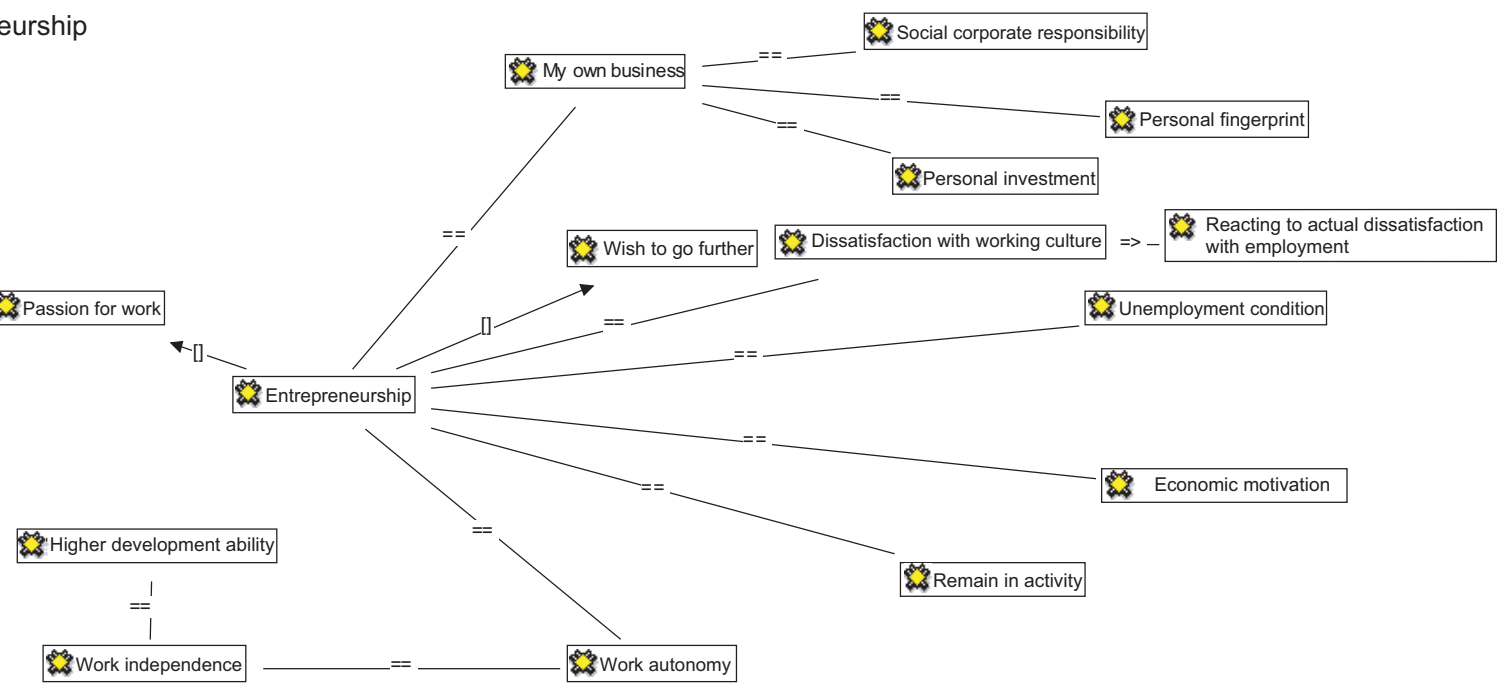

Would-be entrepreneurs
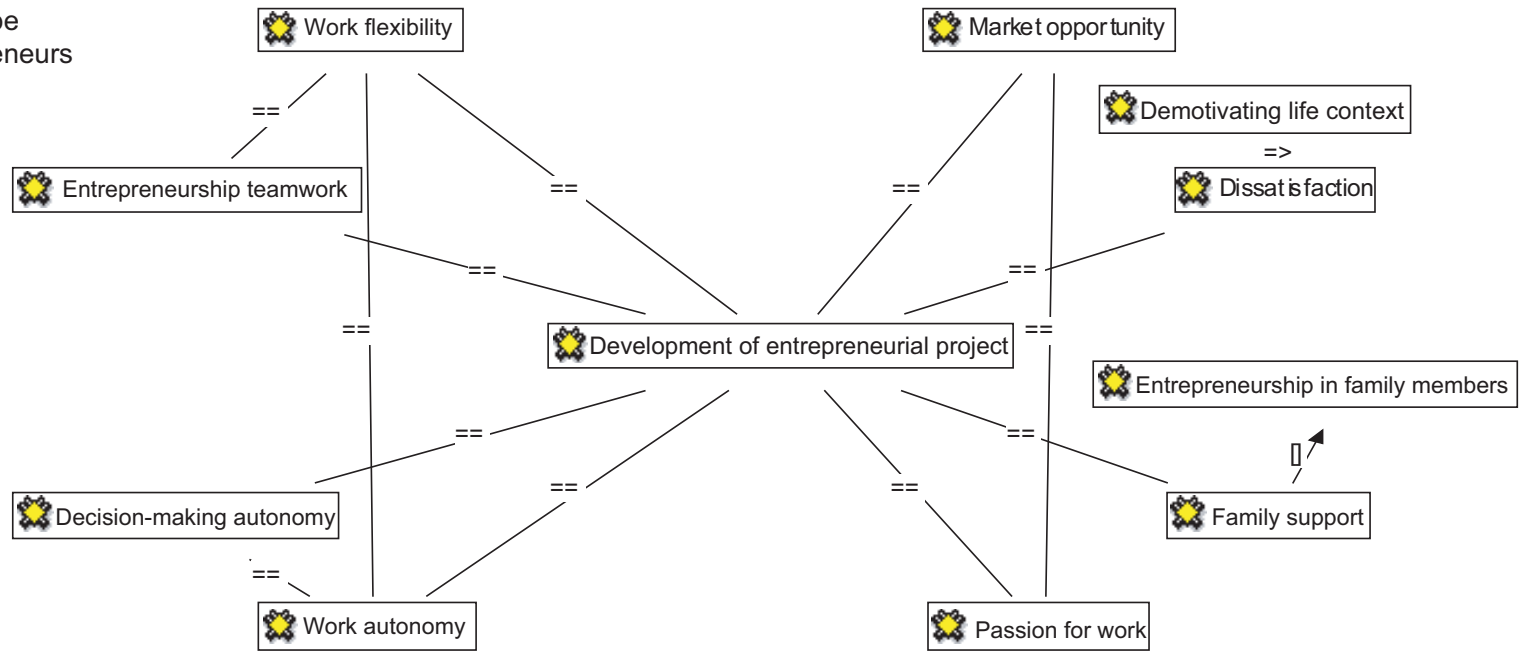

Novice

entrepreneurs

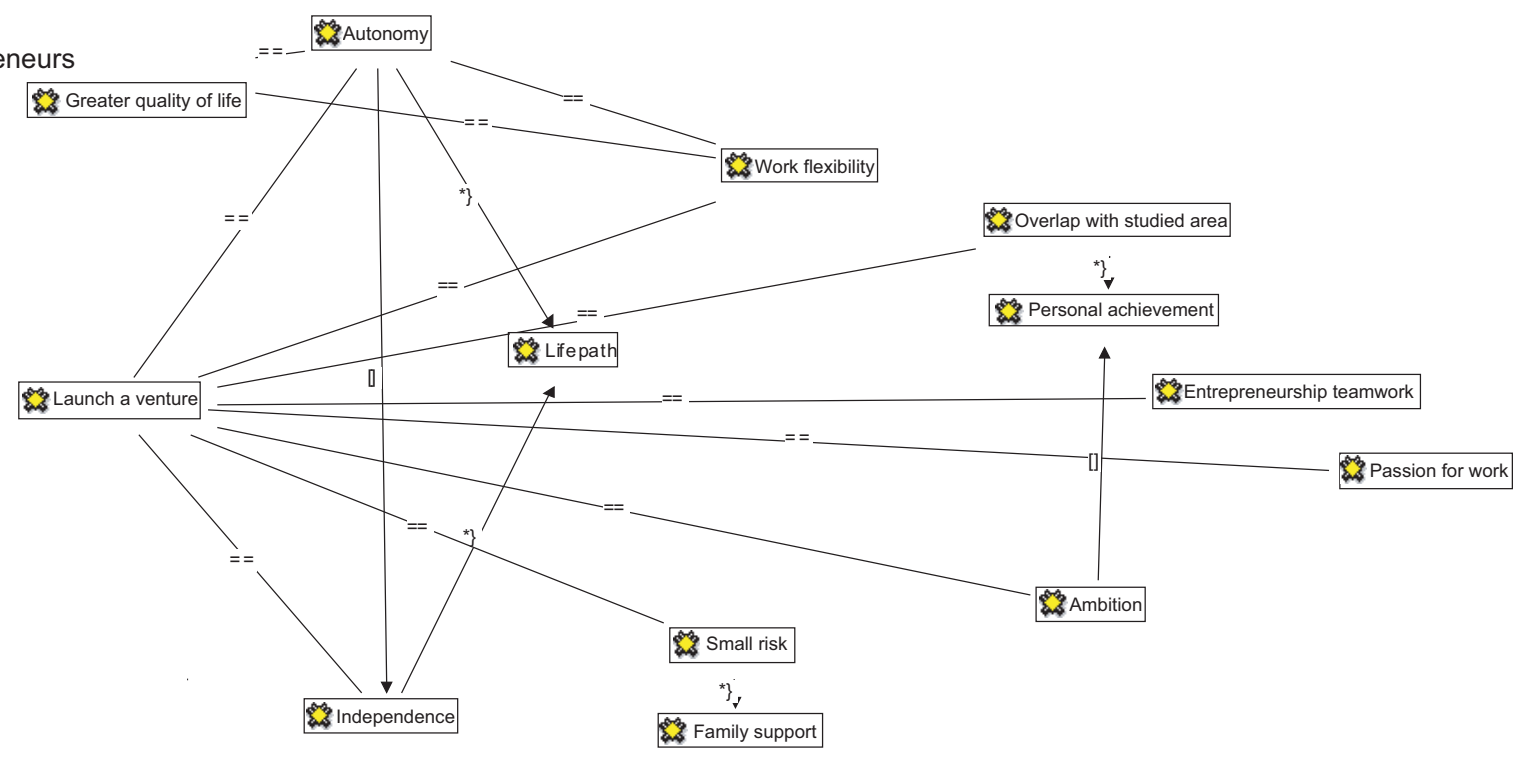

$==$ is associated with

$=>$ is cause of

*\} is property of

[] is part of

Figure 2. Entrepreneurial motivation cognitive maps: entrepreneurship trainees, would-be entrepreneurs and novice entrepreneurs. 
Entrepreneurship

trainees

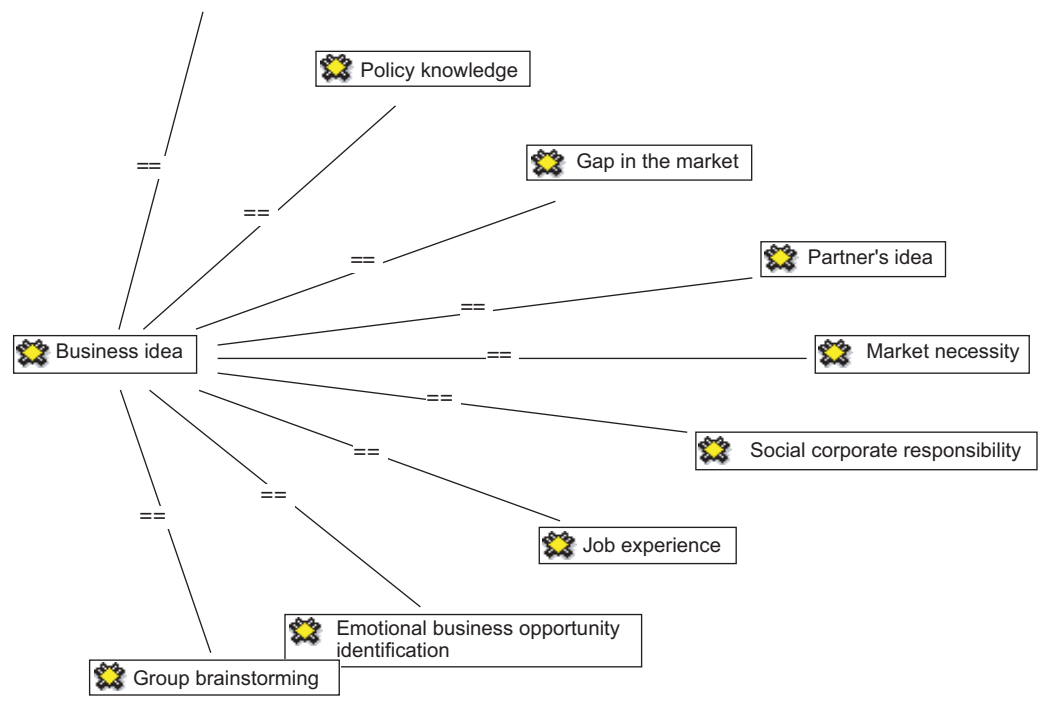

Would-be

entrepreneurs

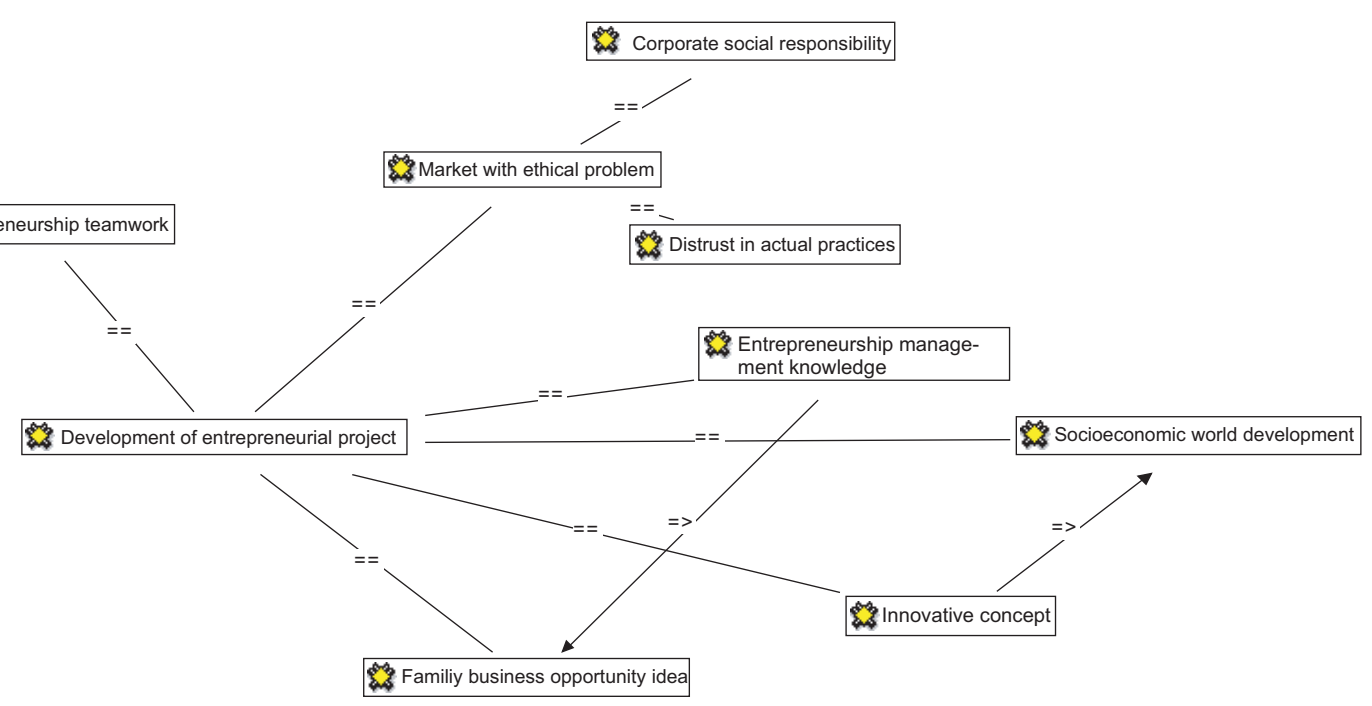

Novice

entrepreneurs

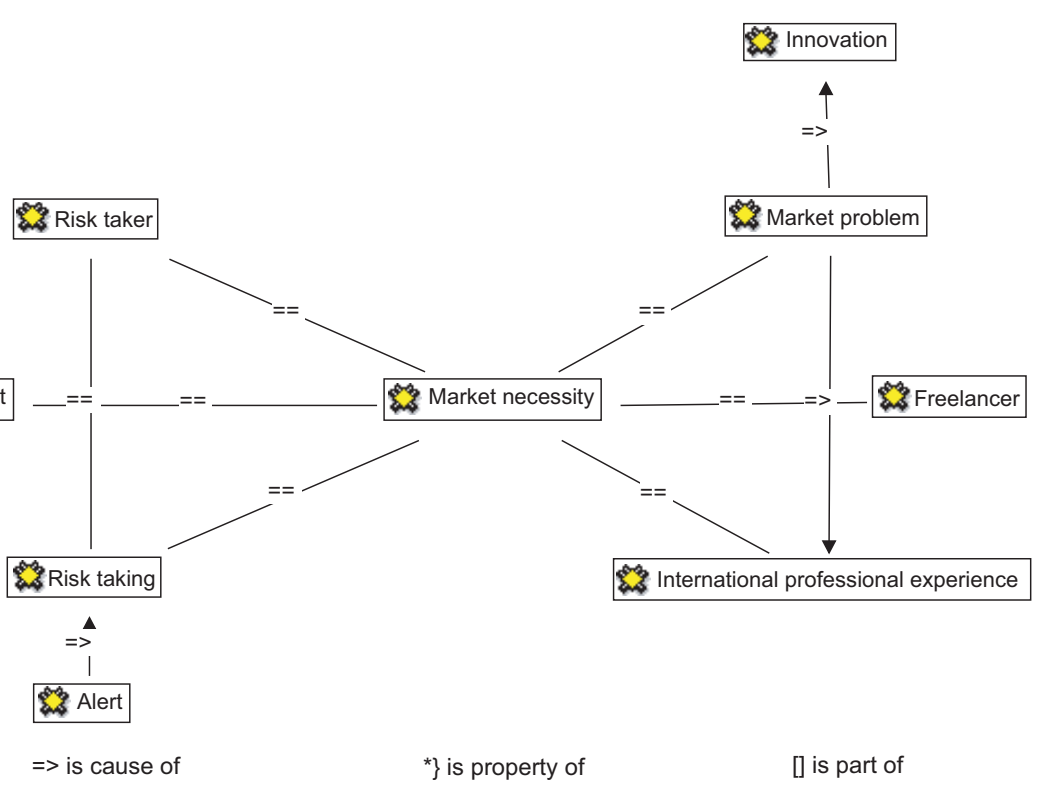

Figure 3. Business opportunity recognition cognitive maps: entrepreneurship trainees, would-be entrepreneurs and novice entrepreneurs. 
Moreover, entrepreneurial teamwork, identified as a motivation, is also present in opportunity recognition.

Concerning novice entrepreneurs, business opportunity recognition emerges from a simple framework. The recognition of a market necessity is associated with an international professional experience, a freelance experience, a market problem identified in a previous job, the socio-demographic development of the country and some propensity for risk taking, as a cause of an alert state. When emerging from past international experience or market problems, business opportunity recognition is associated with the introduction of innovation.

\section{Decision to launch a venture}

First, entrepreneurship trainees' factors leading to the decision to launch a venture are part of the passion for work. Moreover, the decision to launch a venture is associated with environmental factors such as newness to the market (for example, future orientation and originality), the ability to solve market problems, policy knowledge, technical market knowledge, financial resources, differentiation from competitors, market acceptance (as a cause of clients' acceptance), viability (caused by contract definition and critical raw material value) and a profitable value chain.

On the one hand, would-be entrepreneurs associate a decision to launch a venture with passion for work, high levels of motivation and trust in the business area. On the other hand, a decision to launch a venture is based on the assumption that it is a new investment area (for example, an innovative concept based on future orientations and with scientific knowledge applications). The investment is normally small and they have background family support. Concerning the market environment, when deciding to launch a venture, wouldbe entrepreneurs consider the market acceptance, the competition patterns and the belief in the perceived market opportunity, as these are also associated with their passion for work. Moreover, business creation know-how is an important factor.

The decision to launch a venture is associated with novice entrepreneurs' perceived ability to solve market problems, as they know the concurrence and the sociodemographic development of the country that was identified as a market opportunity. At the same time, categories presented in the entrepreneurial motivation cognitive map (Figure 2) are also associated with a decision to launch a venture (for example, the availability of financial resources, the need for independence, the passion for work and the opportunity to choose and work with the entrepreneurial team; see Figure 4).

Overall, with regard to the number of categories elicited and the cognitive maps' structure, novice
Table 4. Domain analysis in cognitive maps: example of categories.

\begin{tabular}{|c|c|}
\hline $\begin{array}{l}\text { Domains in } \\
\text { analysis }\end{array}$ & Categories \\
\hline Macro-social & $\begin{array}{l}\text { Dissatisfaction with working culture; policy } \\
\text { knowledge; gap in the market; technical market } \\
\text { knowledge; financial resources; work autonomy; } \\
\text { work flexibility; professional independence; small } \\
\text { competition patterns; freelancer }\end{array}$ \\
\hline Micro-social & $\begin{array}{l}\text { Entrepreneurship teamwork; family support; } \\
\text { overlap with studied area; group brainstorming; } \\
\text { emotional business opportunity identification; } \\
\text { partner's idea; family business opportunity idea }\end{array}$ \\
\hline Individual & $\begin{array}{l}\text { Economic motivation; remain in activity; } \\
\text { ambition; passion for work; wish to go further; } \\
\text { 'my own business' }\end{array}$ \\
\hline Cognitive & $\begin{array}{l}\text { Decision-making autonomy; small risk; innova- } \\
\text { tive concept; risk taking; ability to solve market's } \\
\text { problems }\end{array}$ \\
\hline
\end{tabular}

entrepreneurs' cognitive maps are clearer, richer and more experience-based than those of would-be entrepreneurs and entrepreneurship trainees. These findings agree with the cognitive psychology assumption that experience increases clarity, richness and reality-basing (Matlin, 2005). Moreover, this evidence is consistent with the results presented by Baron and Ensley (2006).

As predicted, the cognitive map analysis suggests that macro-social (economic, professional and technological), micro-social (family, friends and colleagues), individual (motivation and personality) and cognitive (decision making, opportunity recognition and problemsolving strategies) factors are critical domains during specific business opportunity recognition and the decision to launch a venture for would-be and novice entrepreneurs (Table 4).

Macro-social factors were identified by all the groups in entrepreneurial motivation (for example, dissatisfaction with the working culture), business opportunity recognition (for example, the socio-demographic context; previous international professional experience; freelance experience; socioeconomic world development; policy knowledge) and in the decision to launch a venture (for example, the availability of financial resources; small competition patterns). The role of micro-social factors was also identified by all the groups in the importance of the entrepreneurial teamwork or family support evidence. Moreover, business opportunity recognition can emerge from would-be entrepreneurs' relatives. Life path and cognitive factors were also mentioned as critical, namely in risk-taking propensity and ambition.

It is worth noting that work autonomy, flexibility and independence are central factors that are associated with entrepreneurial motivation in all the groups. Passion for work is also a critical feature, as it is identified as important for motivation, but it is also present in the 
Entrepreneurship

trainees

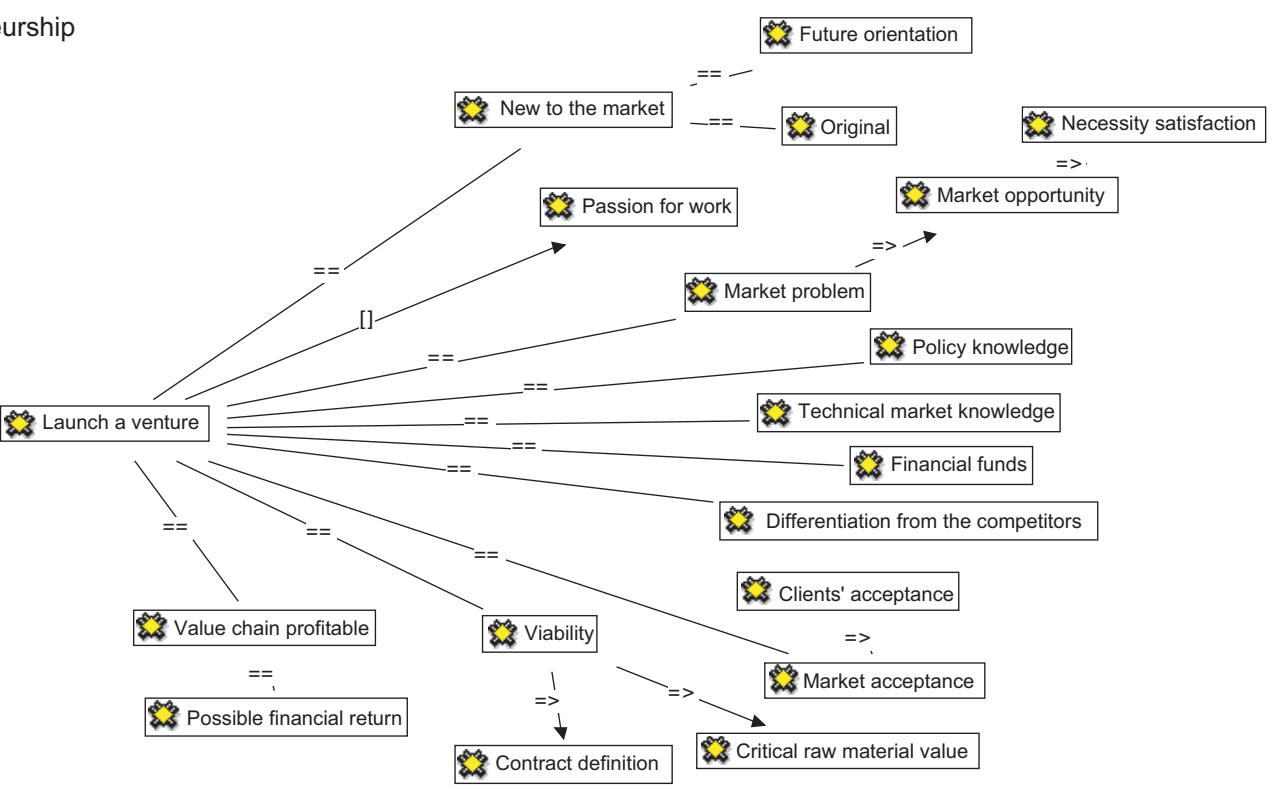

Would-be

entrepreneurs

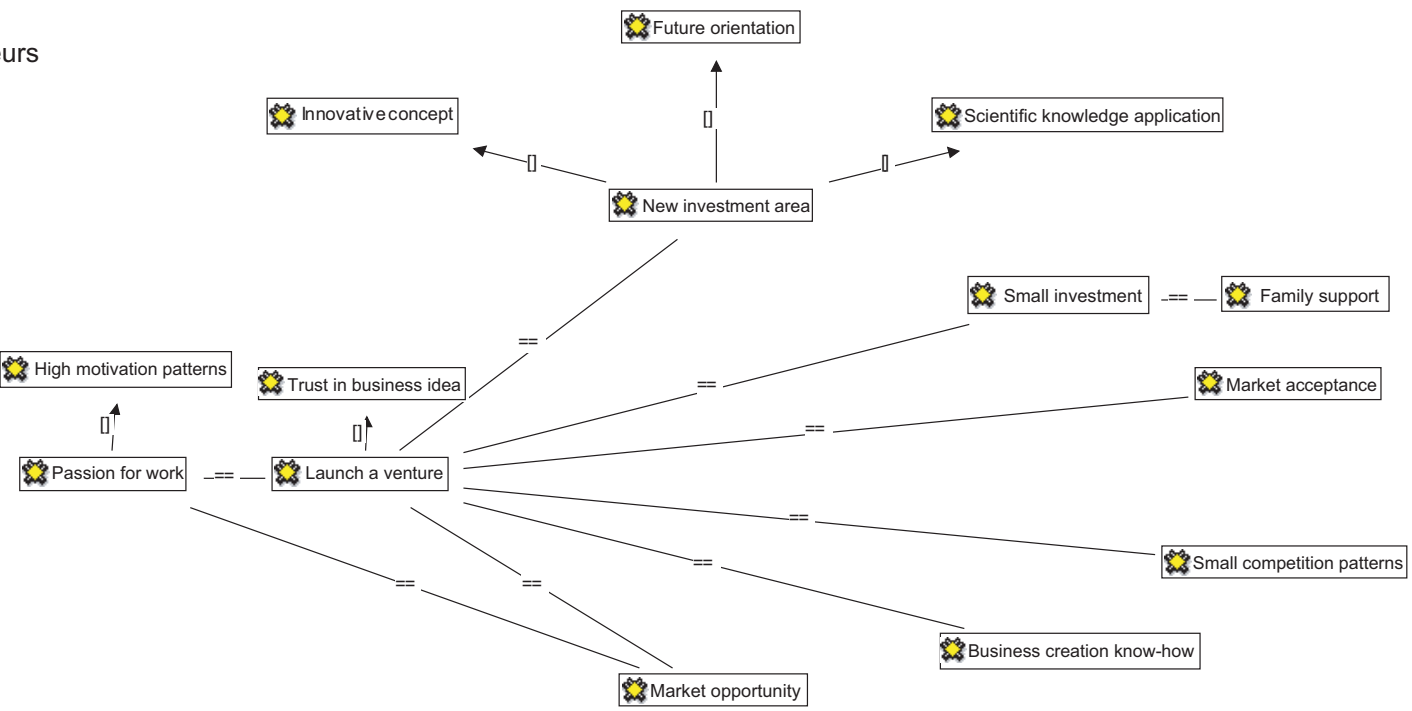

Novice

entrepreneurs

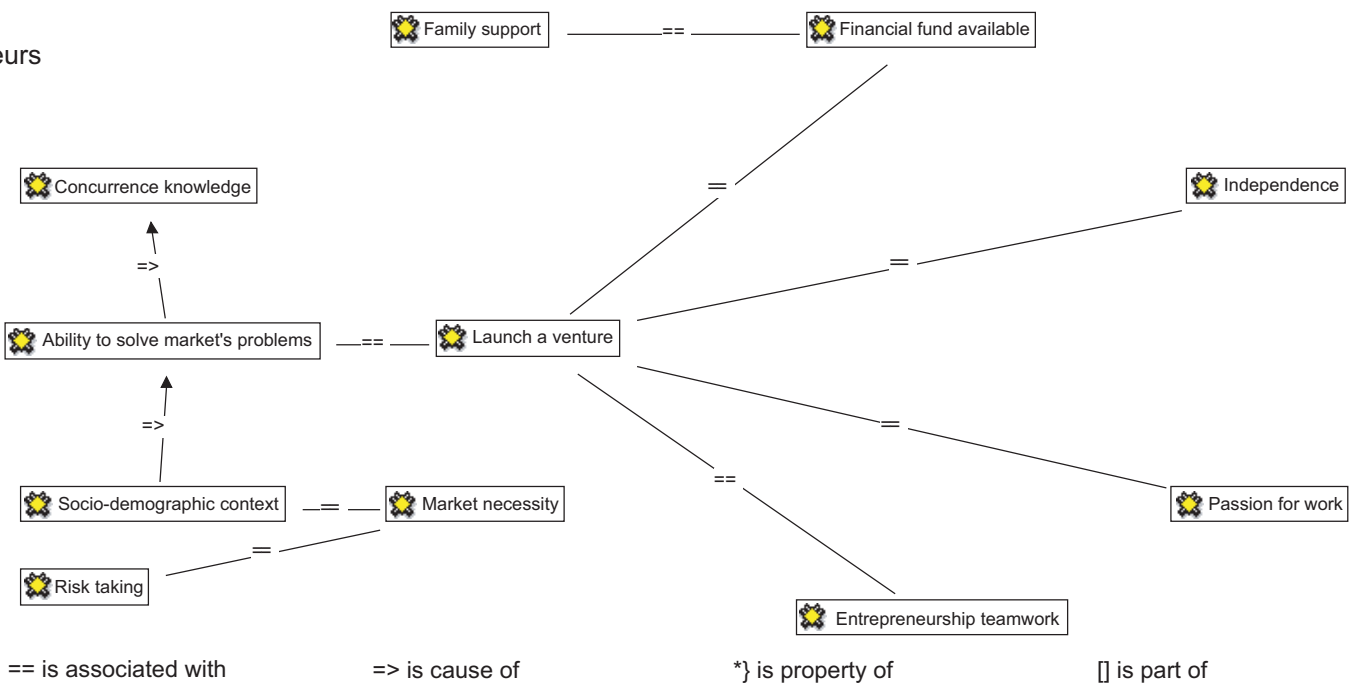

Figure 4. Decision-to-launch-a-venture cognitive maps: entrepreneurship trainees, would-be entrepreneurs and novice entrepreneurs. 
decision to launch a venture cognitive map for all the groups.

However, a business opportunity recognition cognitive map from entrepreneurship trainees is very simple and more linear. This is an interesting map as it reports the academic knowledge acquired from an entrepreneurship graduate-level training course. In fact, policy knowledge, a gap in the market and perceived market necessities are referred to in most entrepreneurship textbooks as business opportunity sources. Moreover, entrepreneurship trainees are seeking business opportunities from all possible sources, suggesting dispersed attention and a lack of fitness for the environment.

\section{Discussion}

The main goal of this exploratory study is to contribute to the clarification of the dynamics of the entrepreneurship process. Indeed, through semi-structured interviews, it was possible to extract cognitive maps of entrepreneurship trainees, would-be entrepreneurs and novice entrepreneurs concerning entrepreneurial motivation, business opportunity recognition and the decision to launch a venture.

Overall, the comparison between the cognitive maps' data suggests that entrepreneurship experience develops the structure of cognitive maps, increasing clarity, richness and experience-based features in cases from entrepreneurship trainees to novice entrepreneurs. So it can be assumed that experience in entrepreneurship changes cognitive maps over time, since cognitive maps become clearer and richer as one moves from entrepreneurship trainees to novice entrepreneurs.

Business opportunities and the decision to launch a venture prototype, identified by Baron and Ensley (2006), were not all present in this research. This may be due to the fact that their data were obtained from experienced (repeat) and novice (first-time) American entrepreneurs. In this paper, we focused on entrepreneurship trainees, would-be entrepreneurs and novice entrepreneurs. As the American model is not universal, it is not strange that prototypical features are not coincident, since culture may have an important impact. Future research should study early stages of entrepreneurship in other cultures too, driven by the new innovative and provocative research paradigm (see Tan et al, 2009).

The model proposed in this research suggests a dynamic-mediation framework, assuming a strong relationship between entrepreneurial motivation and the decision to launch a venture, mediated by business opportunity recognition. However, the analysis of the present data suggests that this model must be further developed. In fact, the data provide evidence that a few motivations associated with entrepreneurial intentions, such as passion for work, were also present in decisions to launch a venture. This evidence suggests that motivation is not only a critical input to the entrepreneurial process, but that it is also important in decision stages, having a systematic influence on them, as Shane, Locke and Collins (2003) have already suggested.

Thus, the present research proposes a development of the previous model according to data evidence from early entrepreneurship stages in which motivation has not only an active catalytic effect, but also a moderating role in business opportunity recognition and the decision to launch a venture.

A decision to launch is the output from entrepreneurship's early stages, and it will only occur when high motivational patterns are perceived, suggesting a moderating role of entrepreneurial motivation. Future research should test this model, including both mediation and moderation effects. As passion for work has already been identified as a crucial feature of venture growth (for example, Baum, Locke and Smith, 2001), it is also important to explain its importance in the initial stages of the entrepreneurial process. Moreover, the importance of passion in the entrepreneurial process has been evidenced as crucial across the successful venture launch. Cardon et al (2009) worked on a comprehensive model of entrepreneurial passion and developed a theory on the nature and experience of entrepreneurial passion. The authors stressed the importance of entrepreneurial passion in the entrepreneur's self-identity, recognizing its importance to the regulation of emotional states and management of conflicts, as well as its importance to the venture's employees (Cardon, 2008).

We can also identify the factors mentioned simultaneously by entrepreneurs, would-be entrepreneurs and entrepreneurship trainees in each of the stages (Figure 5).

At an initial stage, work flexibility, passion for work,

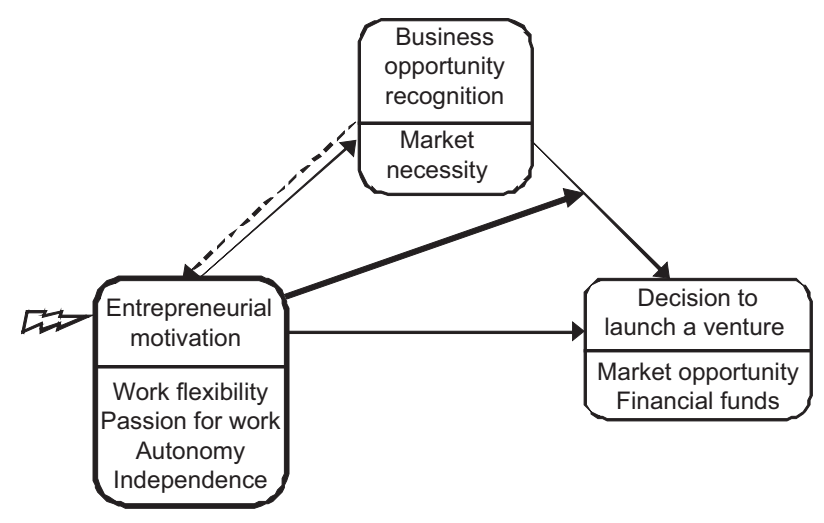

Figure 5. Features shared by entrepreneurs, would-be entrepreneurs and entrepreneurship trainees. 
autonomy and independence are the main motivations within entrepreneurship, suggesting that entrepreneurs wish to have more control over their decision making at work. This motivation leads to business opportunity recognition, mainly through the perception of a necessity in the market. The decision to launch a venture is mainly based on the assumption that there is a profitable market opportunity and financial resources available to invest. At this stage, passion for work is also important, as its high motivational patterns are a determinant of the decision to launch a venture.

Overall, the reported findings contribute to an understanding of how different entrepreneurial experience levels influence entrepreneurial motivations, business opportunity recognition and the decision to launch a venture. Moreover, the present research allows us to design a comprehensive framework between the three early entrepreneurship stages, expanding previous knowledge about entrepreneurial motivation and business opportunity recognition, namely Baron and Ensley's (2006) work.

The present research provides evidence that: (a) there are clear structural and categorical differences between the entrepreneurial motivation, business opportunity and decision to launch a venture cognitive maps of entrepreneurship trainees, would-be entrepreneurs and novice entrepreneurs; (b) novice entrepreneurs show clearer, richer and experience-based early entrepreneurship cognitive maps than would-be entrepreneurs and entrepreneurship trainees; (c) there are simultaneously mentioned factors by entrepreneurs, would-be entrepreneurs and entrepreneurship trainees in each of the stages, suggesting that there are some shared factors among the groups. All the evidence is new to the entrepreneurial literature and provides new avenues for research.

Considering the methodological approach used in the present research, a few limitations should be stated. First, the qualitative data collected could be improved through a triangulation of data collection methods (Flick, 2007, 2009). Second, although clear advantages are provided by ATLAS-ti, the software also attracts some of the typical criticisms of the use of software for social sciences data analysis (see Seidel, 1991).

\section{Practical implications}

This study allows us to infer some practical consequences for the development of academic entrepreneurship programmes. The research provides evidence that entrepreneurship trainees and novice entrepreneurs have different cognitive structures concerning the early stages of entrepreneurship. Thus, we have to be aware that entrepreneurship trainees do not have the same previous experience as novice entrepreneurs. As a consequence, academic programmes must be conducted taking into account the developmental characteristics of trainees' cognitive structures.

Hence it is suggested that entrepreneurship academic programme promoters should take into account the present evidence by designing entrepreneurship programmes that respond to the different experience patterns. Moreover, the programmes should promote simulations of business ideas and the decision to launch a venture (see Sanz-Velasco, 2007).

Improving training on opportunity recognition through important changes in the environment and evaluating opportunities may be crucial to entrepreneurship programmes. The present research shows that entrepreneurial motivational features have an important role between business opportunities and the decision to launch a venture. Thus, it is suggested that entrepreneurial motivation features should be clearly stated at the beginning and throughout the entrepreneurship process, as they have a direct impact on business opportunities and the decision to launch a venture. Similarly, there is a need to expand entrepreneurshiprelated education to non-business students (Shinnar, Pruett and Toney, 2009).

Moreover, focusing attention on the dynamics of motivational and cognitive processes of entrepreneurial ventures may be important for entrepreneurship trainees, helping them to analyse changes in the environment. Promoting entrepreneurial activities and projects during entrepreneurship programmes is also important for enhancing the probability of success.

\section{Acknowledgments}

We would like to thank to the following Professors from ISCTE - IUL who commented on and improved previous drafts of the present research: Professor Ana Passos, Professor Sílvia Silva, Professor Susana Tavares, Professor Nelson Ramalho and Professor Francisco Nunes. This research was supported by Fundação da Ciência e Tecnologia - FCT (SFRH/BD/ 45768/2008).

\section{References}

Baron, R. (2006), 'Opportunity recognition as pattern recognition: how entrepreneurs 'connect the dots' to identify new business opportunities', Academy of Management Perspectives, Vol 20, No 1, pp 104-118.

Baron, R. A. (1998), 'Cognitive mechanisms in entrepreneurship: why, and when, entrepreneurs think differently than other persons', Journal of Business Venturing, Vol 13, pp 275-294.

Baron, R. A. (2004), 'Opportunity recognition: a cognitive perspective', Academy of Management: Best Conference Paper, ENT, pp A1-A6.

Baron, R. A., and Ensley, M. D. (2006), 'Opportunity recognition as the detection of meaningful patterns: evidence from comparisons of novice and experienced entrepreneurs', Management Science, Vol 52, pp 1331-1344.

Baron, R. A., and Shane, S. A. (2005), Entrepreneurship: A 
Process Perspective, Thomson South-Western, Mason, $\mathrm{OH}$.

Barringer, B. R., Jones, F. F., and Neubaum, D. O. (2005), 'A quantitative content analysis of the characteristics of rapidgrowth firms and their founders', Journal of Business Venturing, Vol 20, pp 663-687.

Baum, J. R., and Locke, E. A. (2004), 'The relationship of entrepreneurial traits, skills, and motivation to subsequent venture growth', Journal of Applied Psychology, Vol 89, No 4, pp 587598.

Baum, J. R., Locke, E. A., and Smith, K. G. (2001), 'A multidimensional model of venture growth', Academy of Management Journal, Vol 44, No 2, pp 292-303.

Begley, T. M., Tan, W. L., and Schoch, H. (2005), 'Politicoeconomic factors associated with interest in starting a business: a multi-country study', Entrepreneurship Theory and Practice, Vol 29, No 1, pp 35-55.

Bird, B. (1988), 'Implementing entrepreneurial ideas: the case for intention', Academy of Management Review, Vol 13, No 3, pp 442-453.

Bonito, J. A. (2004), 'Shared cognition and participation in small groups: similarity and member prototypes', Communication Research, Vol 31, pp 704-730.

Bygrave, W. D. (2007), 'The entrepreneurship paradigm (I) revisited', in Neergaard, H., and Ulhoi, J. P., eds, Handbook of Qualitative Research Methods in Entrepreneurship, Edward Elgar, Cheltenham.

Carbonara, N., and Scozzi, B. (2006), 'Cognitive maps to analyse new product development processes: a case study', Technovation, Vol 26, pp 1233-1243.

Cardon, M. S. (2008), 'Is passion contagious? The transference of entrepreneurial emotion to employees', Human Resource Management Review, Vol 18, No 2, pp 77-86.

Cardon, M. S., Wincent, J., Singh, J., and Drnovsek, M. (2009), 'The nature and experience of entrepreneurial passion', Academy of Management Review, Vol 34, No 3, pp 511-532.

Casson, M. (2005), 'The individual-opportunity nexus: a review of Scott Shane: a general theory of entrepreneurship', Small Business Economics, Vol 24, pp 423-430.

Cohen, J. (1960), 'A coefficient of agreement for nominal scales', Educational and Psychological Measurement, Vol 20, pp 3746.

Collins, C. J., Hanges, P. J., and Locke, E. A. (2004), 'The relationship of achievement motivation to entrepreneurial behavior: a meta-analysis', Human Performance, Vol 17, No 1 , pp 95-117.

Cossette, P., and Audet, M. (1992), 'Mapping of an idiosyncratic schema', Journal of Management Studies, Vol 29, No 3, pp 325-347.

Curseu, P. L., Schruijer, S., and Boros, S. (2007), 'The effects of groups' variety and disparity in groups' cognitive complexity', Group Dynamics: Theory, Research, and Practice, Vol 11, No 3, pp 187-206.

Davidson, P. (2004), Researching Entrepreneurship, Springer, New York.

Dutta, K. D., and Crossan, M. M. (2005), 'The nature of entrepreneurial opportunities: understanding the process using the $4 \mathrm{I}$ organizational learning framework', Entrepreneurship Theory and Practice, Vol 11, No 3, pp 425-449.

Eden, C. (1988), 'Cognitive mapping', European Journal of Operational Research, Vol 36, pp 1-13.

Eden, C., and Ackermann, F. (1992), 'The analysis of cause maps', Journal of Management Studies, Vol 29, No 3, pp 309324.

Flick, U. (2007), Managing the Quality of Qualitative Research, Book 8 of the Sage Qualitative Research Kit (8 Volumes), Sage, London/Thousand Oaks, CA/Delhi.

Flick, U. (2009), An Introduction to Qualitative Research, 4 ed, Sage, London/Thousand Oaks, CA/Delhi.

Goodhew, G., Cammock, P., and Hamilton, J. (2005), 'Managers' cognitive maps and intra-organisational performance differences', Journal of Managerial Psychology, Vol 20, No 2, pp 124-136.
Henwood, K., and Pidgeon, N. (2003), 'Grounded theory in psychological research', in Camic, P. M., Rhodes, J. E., and Yardley, L., eds, Qualitative Research in Psychology: Expanding Perspectives in Methodology and Design, American Psychological Association, Washington, DC, pp 131-155.

Intraub, H., Bender, R. S., and Mangels, J. A. (1992), 'Looking at pictures but remembering scenes', Journal of Experimental Psychology: Learning, Memory, and Cognition, Vol 18, No 1, pp 180-191.

Kickul, J., and Gundry, L. K. (2000), 'Pursuing technological innovation: the role of entrepreneurial posture and opportunity recognition among internet firms', Frontiers of Entrepreneurship Research: Proceedings of the Twentieth Annual Entrepreneurship Research Conference, Wellesley, MA, pp 200-209.

Langfield-Smith, K. (1992), 'Exploring the need for a shared cognitive map', Journal of Management Studies, Vol 29, No 3, pp 349-368.

Laukkanen, M. (1998), 'Conducting causal mapping research: opportunities and challenges', in Eden, C., and Spender, J.C., eds, Managerial and Organizational Cognition: Theory, Method and Research, Sage, London.

Levenburg, N. M., Lane, P. M., and Schwarz, T. V. (2006), 'Interdisciplinary dimensions in entrepreneurship', Journal of Education for Business, Vol 81, No 5, pp 275-281.

Lincoln, Y., and Guba, E. (1985), Naturalistic Inquiry, Sage, New York.

Matlin, M. W. (2005), Cognition, 5 ed, Harcourt College Publishers, Fort Worth, TX

McGee, J. E., Peterson, M., Mueller, S. L., and Sequeira, J. M. (2009), 'Entrepreneurial self-efficacy: refining the measure', Entrepreneurship Theory and Practice, Vol 33, No 4, pp 965988.

McMullen, J. S., Plummer, L. A., and Acs, Z. J. (2007), 'What is an entrepreneurial opportunity?' Small Business Economics, Vol 28, pp 273-283.

Muhr, T. (2004), ATLAS.ti User's Manual and Reference, Scientific Software Development, Berlin.

Palmer, S. E. (1977), 'Fundamental aspects of cognitive representation', in Rosch, E., and Lloyd, B. B., eds, Cognition and Categorization, Lawrence Erlbaum Associates, Mahwah, NJ, pp 259-303.

Plummer, L. A., Haynie, J. M., and Godesiabois, J. (2007), 'An essay on the origins of entrepreneurial opportunity', Small Business Economics, Vol 28, pp 363-379.

Rosch, E. (1977), 'Principles of categorization', in Rosch, E., and Lloyd, B. B., eds, Cognition and Categorization, Lawrence Erlbaum Associates, Mahwah, NJ, pp 27-48.

Sanz-Velasco, S. A. (2007), 'Opportunity development as a learning process for entrepreneurs', International Journal of Entrepreneurial Behaviour and Research, Vol 12, No 5, pp 251-271.

Seidel, J. (1991), 'Method and madness in the application of computer technology to qualitative data analysis', in Fielding, N., and Lee, R. M., eds, Using Computers in Qualitative Research, Sage, London.

Shane, S. (2003), A General Theory of Entrepreneurship: The Individual-Opportunity Nexus, Edward Elgar Publishing, Cheltenham.

Shane, S., Locke, E. A., and Collins, C. J. (2003), 'Entrepreneurial motivation', Human Resource Management Review, Vol 13, pp 257-279.

Shane, S., and Venkataraman, S. (2000), 'The promise of entrepreneurship as a field of research', Academy of Management Review, Vol 25, pp 217-226.

Shinnar, R., Pruett, M., and Toney, B. (2009), 'Entrepreneurship education: attitudes across campus', Journal of Education for Business, Vol 84, No 3, pp 151-159.

Short, J. C., Broberg, J. C., Cogliser, C. C., and Brigham, K. H. (2009), 'Construct validation using computer-aided text analysis (CATA)', Organizational Research Methods (forthcoming), pp 1-28. 
Siqueira, A. C. O. (2007), 'Entrepreneurship and ethnicity: the role of human capital and family social capital', Journal of Developmental Entrepreneurship, Vol 12, No 1, pp 3146.

Smith, B. R., Matthews, C. H., and Schenkel, M. T. (2009), 'Differences in entrepreneurial opportunities: the role of tacitness and codification in opportunity identification', Journal of Small Business Management, Vol 47, No 1, pp 38-57.

Strauss, A., and Corbin, J. (1998), 'Grounded theory methodology: an overview', in Denzin, N. K., and Lincoln, Y. S., eds, Strategies of Qualitative Inquiry, Sage, Thousand Oaks, CA, pp 158-183.

Swan, J. A. (1995), 'Exploring knowledge and cognition in decisions about technological innovation: mapping managerial cognitions', Human Relations, Vol 48, No 11, pp 1241-1270.

Tan, J., Fischer, E., Mitchell, R., and Phan, P. (2009), 'At the center of the action: innovation and technology strategy research in the small business setting', Journal of Small Business Management, Vol 47, No 3, pp 233-262.

Tolman, E. C. (1948), 'Cognitive maps in rats and men', Psychological Review, Vol 55, No 4, pp 189-208.

Vijaya, V., and Kamalanabhan, T. J. (1998), 'A scale to assess entrepreneurial motivation', Journal of Entrepreneurship, Vol 7, No 2, pp 183-198.

Zhao, H., and Seibert, S. E. (2006), 'The big five personality dimensions and entrepreneurial status: a meta-analytical review', Journal of Applied Psychology, Vol 91, No 2, pp 259271. 